\title{
Identification of Cytological and Morphological Characteristics of Some Barley Landraces
}

\author{
Amer. M. Abel Aziz 1
}

\begin{abstract}
This work was carried out at the Farm of Faculty of Agriculture, Alexandria University. This work was carried out using 16 land races of Barley and 7 characters for plant growth as well as investigation of karyotype were carried out. The obtained data indicated that there are significant differences between the tested land races and fourteen chromosomes were detected in karyotype for each land race. This work recommends the use of these data for the selection and breeding program.
\end{abstract}

\section{INTRODUCTION}

Barley (Hordeum vulgar L.) is a major crop ranked fourth in the world-wide production of cereals. It is considered a primary staple food or feed crop in the semi-arid tropics of Asia, Africa, and South America. Th grain is normally used as food and animal fodder, but recently it has been used as raw material for the production of beer. Barley is typically cultivated in the arid and semi-arid regions of Iran generally in areas with low precipitation that are not suitable for wheat (Baik and Ullrich, 2008). Drought is a signifiant limiting factor for agricultural productivity and generally inhibits plant growth through reduced water absorption and nutrient uptake. For improving the drought tolerance of crop varieties by plant breeding, it is necessary to identify genotypes with tolerance to drought stress during all growth stages. Landraces are still cultivated in traditional crop-growing areas (Araus et al, 2008). There is renewed interest in landraces and primitive cultivars as important sources of genetic variation (Brush, 1995 and Rajaram \&Ginkle,2001) mainly because of the trend toward greater uniformity that has narrowed the genetic base of modern cultivars, thus increasing their vulnerability to biotic and abiotic stress. Decreased water availability generally results in reduced growth and fial yield in crop plants. Plant drought tolerance is a highly complex trait that involves multiple genetic, physiological and biochemical mechanisms (Baik and Ullrich, 2008; Erdei et al., 2002). Drought affets morphological, physiological, biochemical and molecular processes in plants resulting in growth inhibition. Th extent of these changes is dependent on the time, stage and severity of environmental stress (Cao et al., 2011). Measurements of diffrent physiological processes of plants responses to drought are important information on the various strategies of the plant intended to remove or to reduce the harmful effcts of water defiit in soil or plant tissues. Water defiit conditions cause water losses within the plant and result in relative water content (RWC) reduction. Threfore, RWC is widely used as one of the most reliable indicators for defiing both the sensitivity and the tolerance of plants to water defiit (Rampino et al., 2006; Sanchez-Rodriguez et al., 2010). Rong-Hua et al. (2006) and Farshadfar et al (2012) concluded that chlorophyll content could be considered as a reliable indicator in screening barley genotypes for drought tolerance. Experiments with a host of plants and different photosynthetic metabolism processes, which can be induced by varieties of plants and many biotic and abiotic factors, can directly or indirectly produce modifiation to florescence induction kinetics. In addition, Slapakauskas and Ruzgas (2005) reported that measuring of chlorophyll provides information on quantitative and quantitative changes in photosynthesis.

\section{MATERIALIS AND METHODS}

\section{Plant material}

Barley (16 landraces) have been investigated under normal conditions and this research was carried out in farm of Faculty of Agriculture Alexandria University and Laboratory of cytogenetics under the help offered by Professor Mohammed El-Seehy.

\section{Morphological Identification:}

For the 16 different genotyped were carried out. These characters are (Growth habit, The presence of hairs on the lower leaves sheath, The degree of discoloration auricles flag leaf to Anthocyanin, The percent of the curved flag leaves, The presence of wax on neck the flag leaf, The presence of wax on the stem and Covers grain).

Cytological examination was carried after germination of seeds and when roots with 1-2 cm long were obtained. The root tips collected from these seeds were fived in ethanol and glacial acetic acid 3:1.

\section{Preparation of chromosomes:}

The fived root-tips were thoroughly washed with distilled water, hydrolysed with $5 \mathrm{M} \mathrm{HCL}$ at $29^{\circ} \mathrm{C}$ for $30 \mathrm{~min}$., then they were washed and transferred into vial samples containing basic-fuchsin, $\mathrm{p}^{\mathrm{H}} 2.4$ for $3 \mathrm{hrs}$, washed with distilled water, transferred to $45 \%$ acetic acid and examined Seehy (1989).

\footnotetext{
${ }^{1}$ Genetic Resources Research Department Field Crops

Research Institute, ARC- Giza, Cairo

Received November 9, 2014, Accepted December 21, 2014
} 


\section{RESULTS AND DISCUSSION}

The results obtained indicated that there was no differences between the different genotypes at the level of chromosome number and, since the chromosome number was found to be 14 chromosome. However

Table 1.

\begin{tabular}{cccc}
\hline Genotype & Chromosome Number & Genotype & Chromosome Number \\
\hline $1-7543$ & 14 & $9-7458$ & 14 \\
\hline $2-7436$ & 14 & $10-7466$ & 14 \\
\hline $3-7440$ & 14 & $11-7471$ & 14 \\
\hline $4-7441$ & 14 & $12-7476$ & 14 \\
\hline $5-7442$ & 14 & $13-7479$ & 14 \\
\hline $6-7450$ & 14 & $14-7483$ & 14 \\
\hline $7-7452$ & 14 & $15-7485$ & 14 \\
\hline $8-7454$ & 14 & $16-7489$ & \\
\hline
\end{tabular}

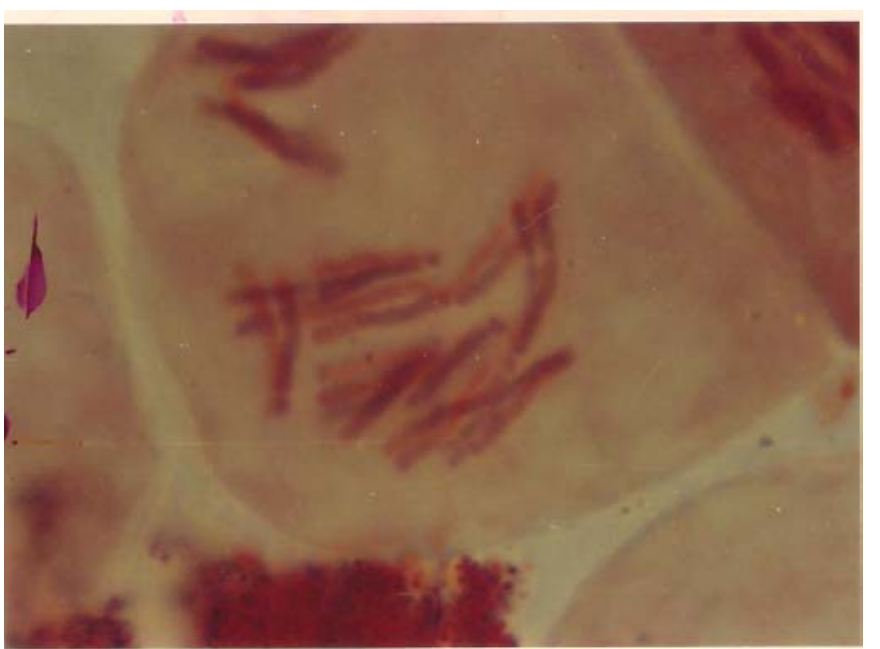

Figure 1. Photomicrograph showing Hetero peknosis.

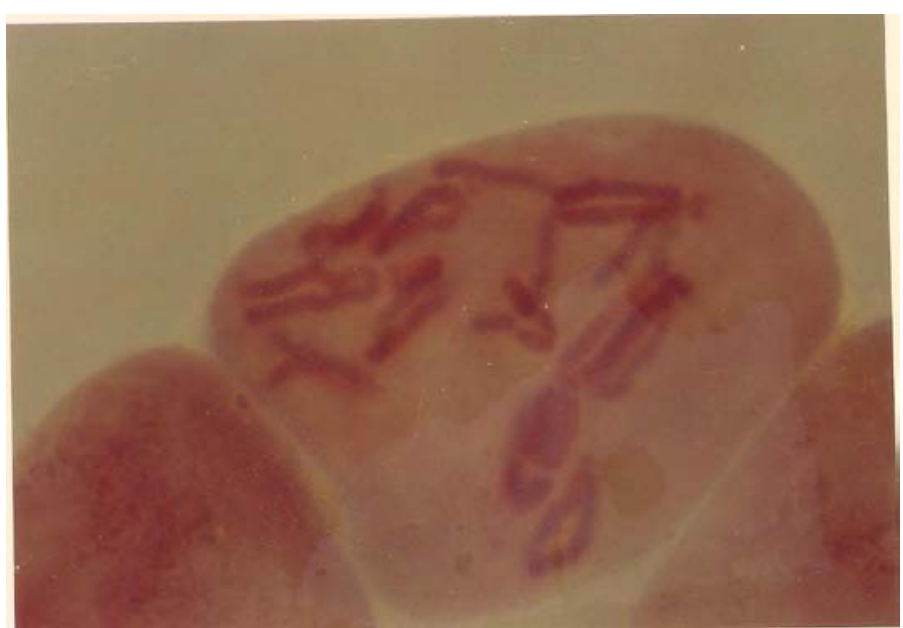

Figure 2. Photomicrograph showing metaphase polar view with high degree of stikiness. 


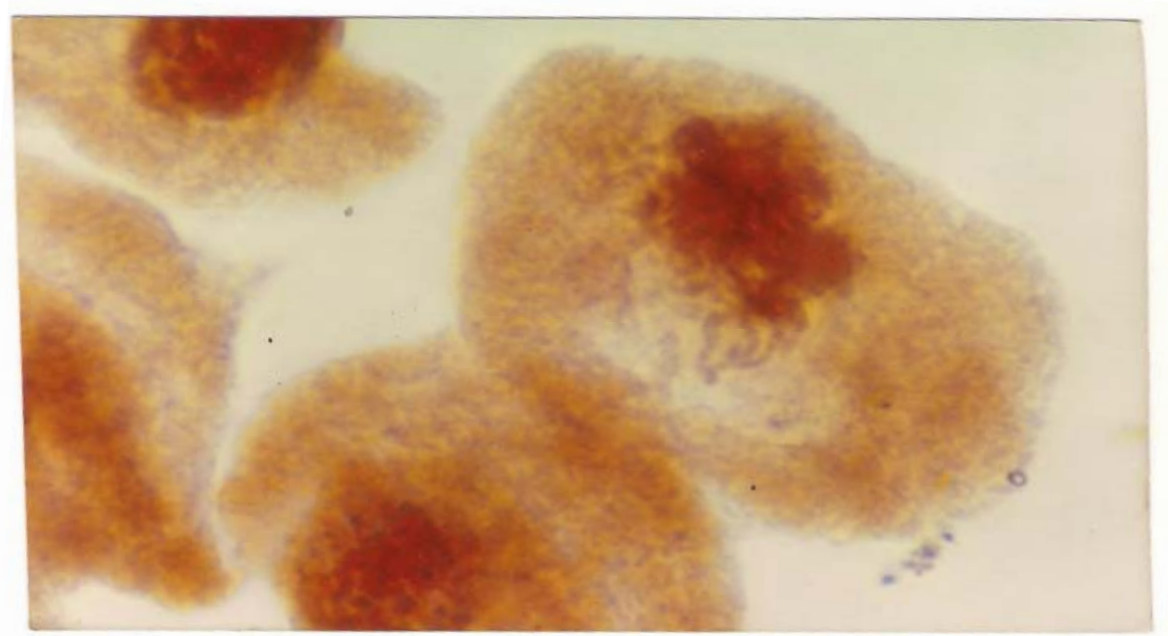

Figure 3. Photomicrograph showing metaphase stage with fragments.

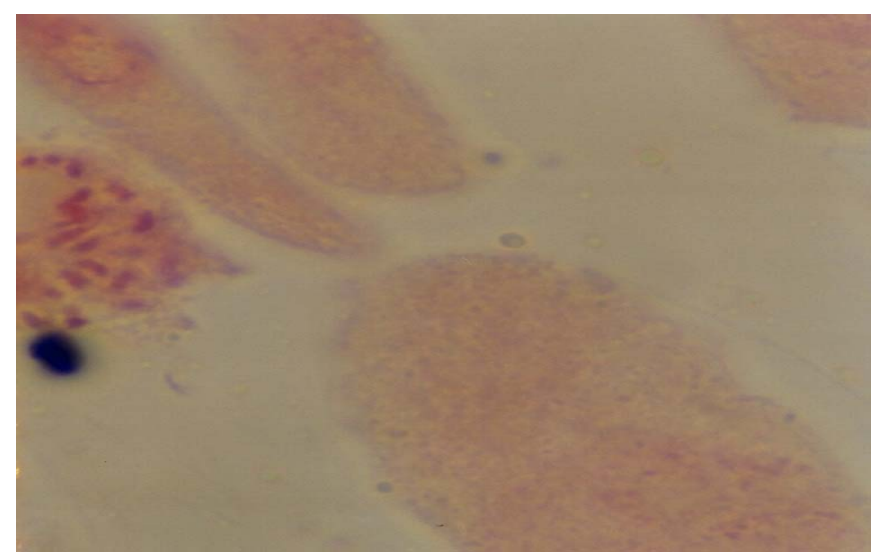

Figure 4. Photomicrograph showing metaphase stage showing metaphase polar view.

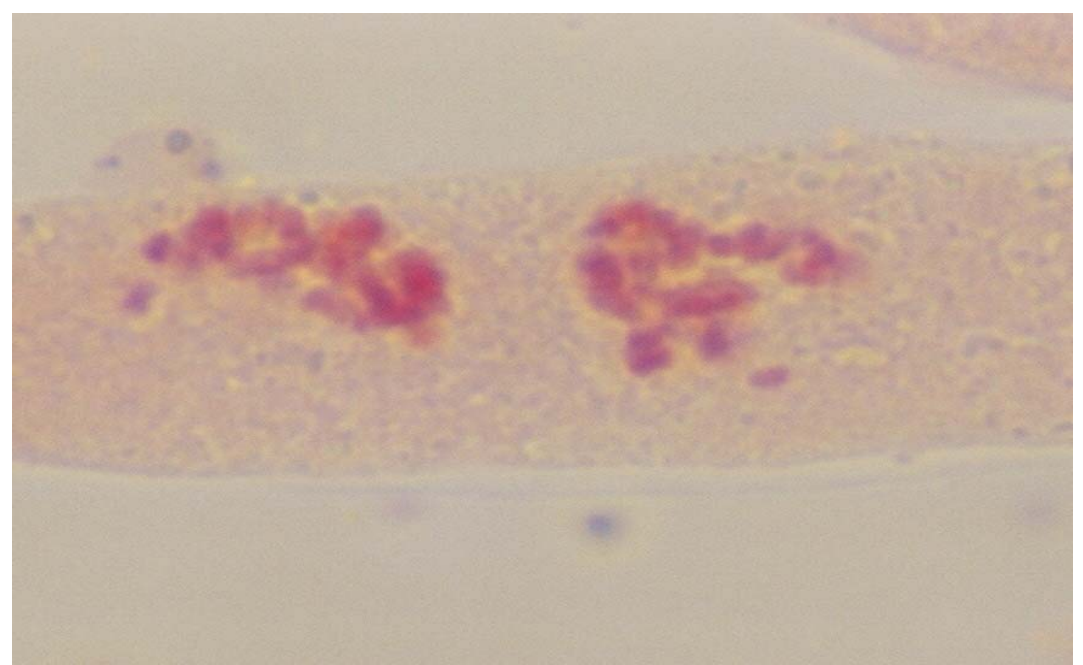

Figure 5. Photomicrograph showing metaphase stage with polar view (polyploidy). 
Figure 6. Photomicrograph showing metaphase stage showing diploid chromosome number.

Figure 7. Photomicrograph showing metaphase stage showing two chromosome complement.

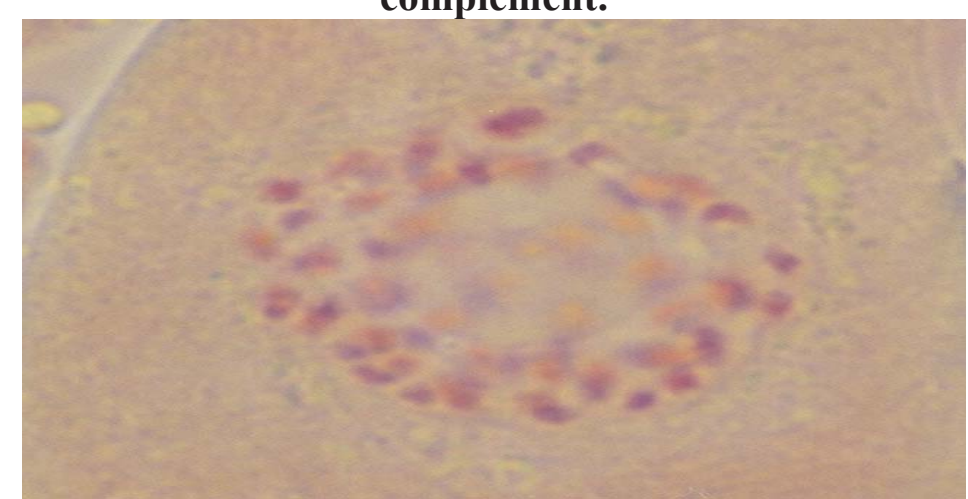

Figure 8. Photomicrograph showing metaphase stage showing chromosome with stickiness and fragment. 
Figure 9. Photomicrograph showing metaphase stage showing stickiness and fragment.

Figure 10. Photomicrograph showing metaphase stage with hyperpolid.

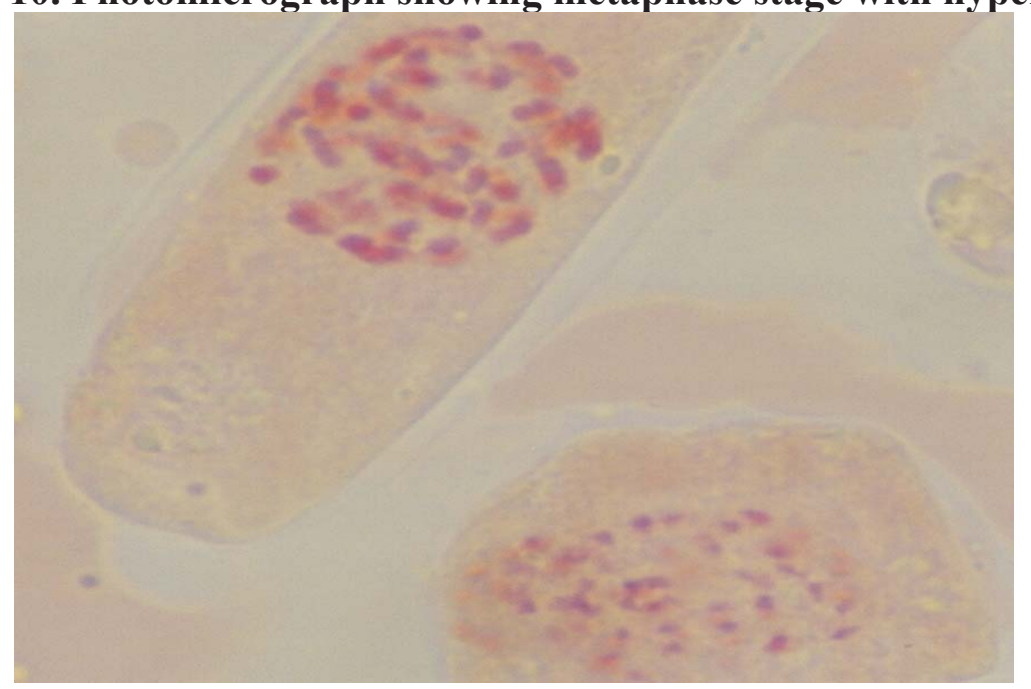

Figure 11. Photomicrograph showing Interphase neucleus. 


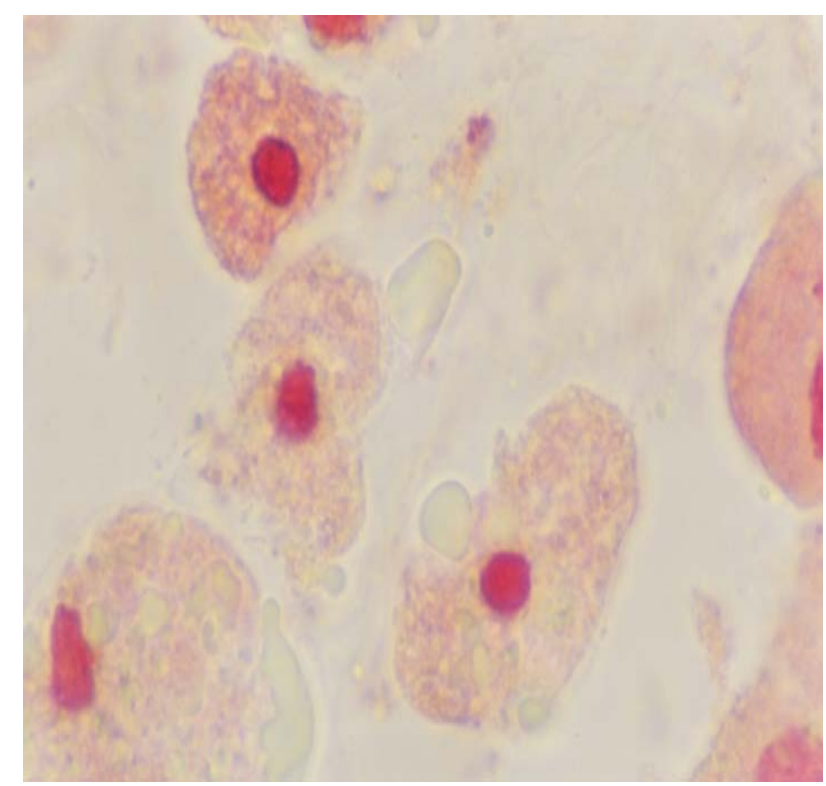

Figure 12. Photomicrograph showing Interphase with heterochromatin

Figure 13. Photomicrograph showing chromosome complement at metaphase stage. 


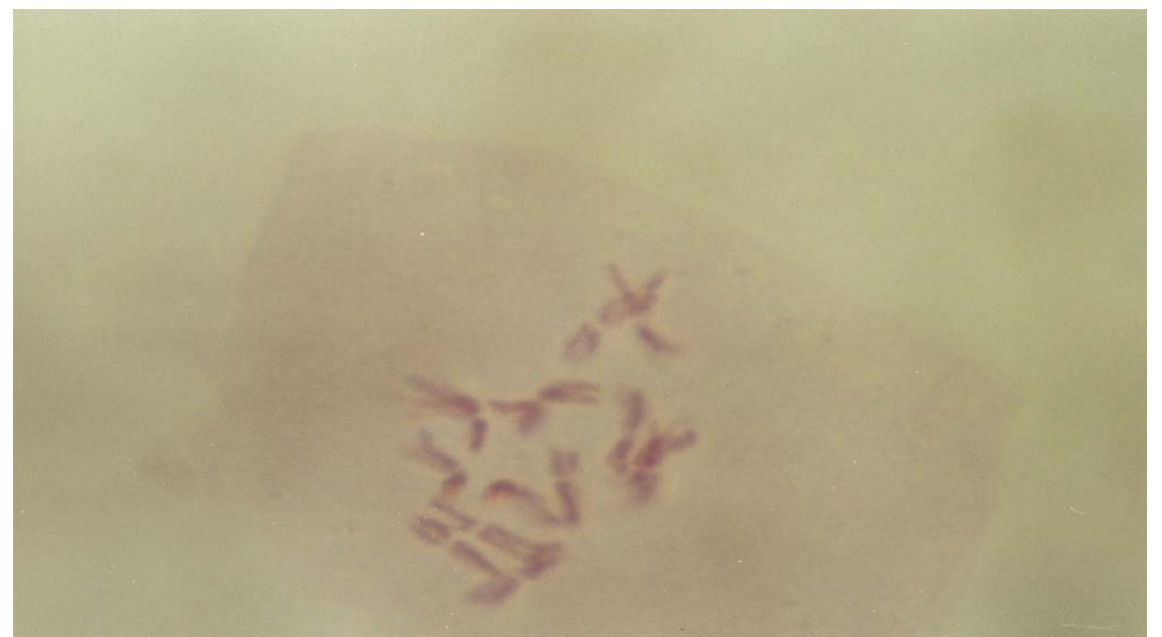

Figure 14. Photomicrograph showing metaphase stage.

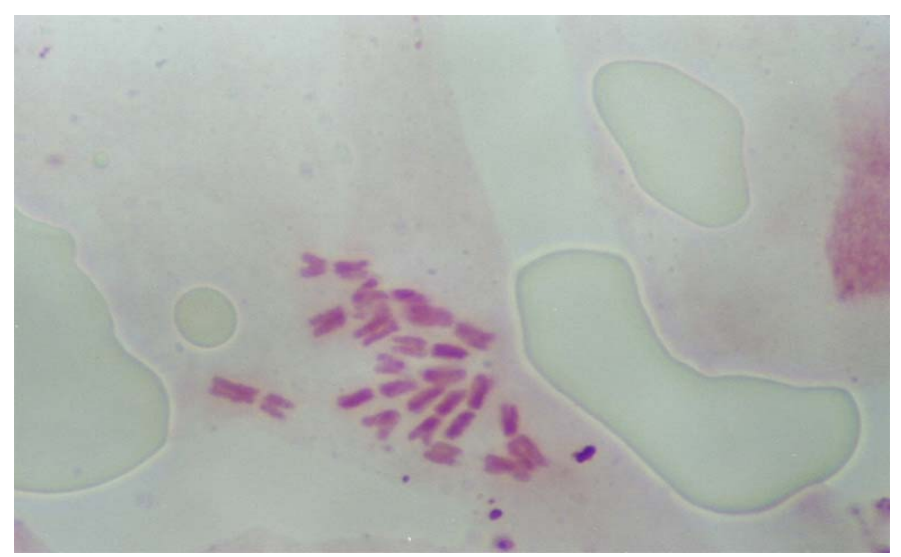

Figure 15. Photomicrograph showing metaphase stage with stickiness.

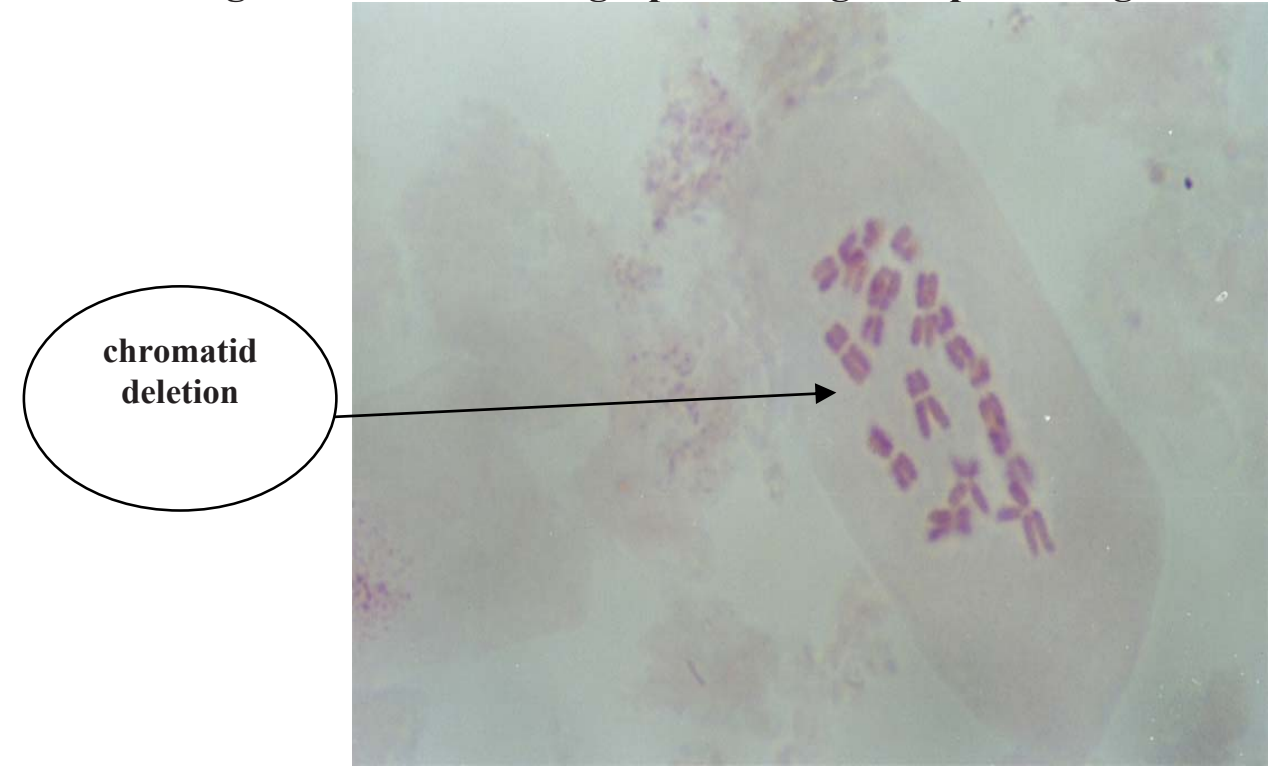

Figure 16. Photomicrograph showing metaphase stage with chromatid deletion. 
These characters displayed highly significant differences between the different genotypes.

The author wishes to thank Professor Dr. Mohammed El-Seehy for his help and his support for this research.

\section{REFERENCES}

Araus JL, Salfer MP, Royo C, Serett MD (2008). Breeding for yield potential and stress adaptation in cereals, Critical Rev in Plant Sci. 27: 377-412.

Baik BK, Ullrich SE (2008). Barley for food: Characteristics, improvement, and renewed interest, Journal of Cereal Science, 48 (2): 233-242.
Erdei L, Tari I, Csisza'r J, Pe'csva'radi A, Horva'th F, Szabo M, Ordog M, Cseuz L, Zhiponova M, Szilak L, Gyorgyey L (2002). Osmotic stress responses of wheat species and cultivars differing in drought tolerance: some interesting genes (advices for gene hunting), Acta Biol. Szeged. 46: 63-65.

Farshadfar E, Elyasi P, Aghaee M (2012). In Vitro selection for drought tolerance in common wheat (Triticum aestivum L) genotypes by mature embryo culture, Americ J Scien Res. 48: 102-115.

Naghaii V, Asgharipour MR (2011). Different in drought stress responses of 20 barley genotypes with contrasting drought tolerance during grain filling, Advance in Environment Biology, 5(9): 3042-3049.

Rajaram S, Van Ginkle M (2001). Mexico, 50 years of international wheat breeding, Bonjean AP, Angus WJ, (Eds.), The World Wheat Book: A History of Wheat Breeding. Lavoisier Publishing, Paris, France. 579-604.

Seehy, M. A. 1989. Sister chromatid exchanges induced by lannate. Bull. High Inst. Pulic Health., XIX,4: 993-1000.

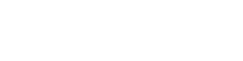

\section{تحيد بهض الصفل الموفولوجية والوراثية الخلوبة لجض الأصط الورالثية لنبل الثعير}

$$
\text { محمد عبد العزيزمحمد علمر }
$$

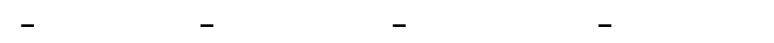

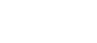

وأوضحت الدرلسة كما هوموضح في الجدول رقم (r)

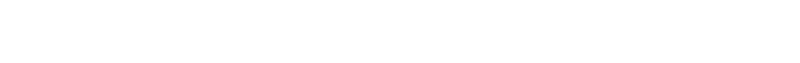

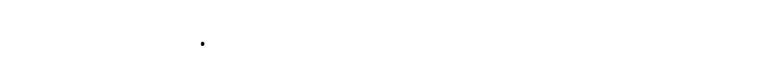
أغلفة الحبة الموجودة في لمل الترلكي الوراثية الستة عثر. وكذلك م الحصول على خلايا القمة النلمي ـة للج ذور

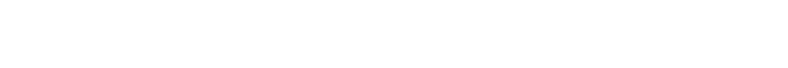
الاتقسل الميتوزي هذا وقد أظلهرت النتائج المتحصل عليها

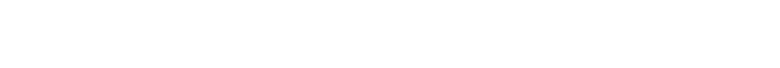
الفحوص الميكروسكوبية انها جميعها تحتوي على عدد عا عالف

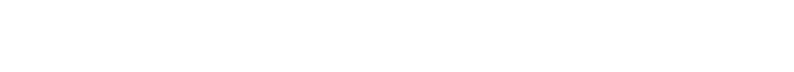
برلمج الانتخلب والتربية المسنقبلية.
لجري هذا البحث بمزرعة كلية الزراعة ومعل اللمية

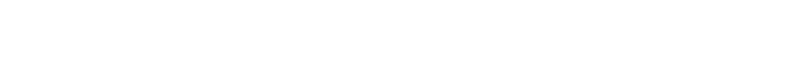

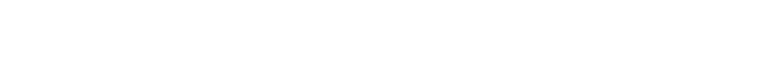

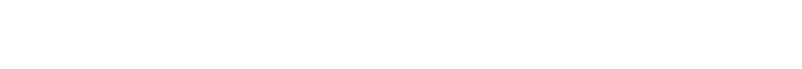
توصففسع صفلت على النبلت وهي: ا -طبيعة النم ـو.

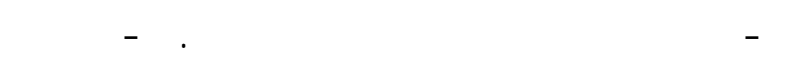
تلون أنينت ورقة العلم بالأثنوسيانين. ع - نسبة أوراق العلم الملتوية. 0 - وجود للثمع على ورقة العل م. 7 - وج -ود التها

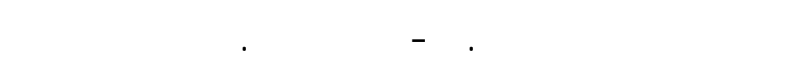

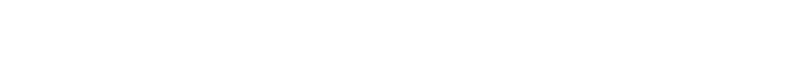

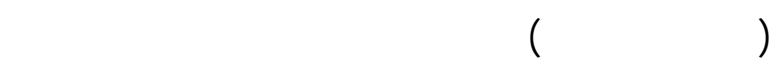

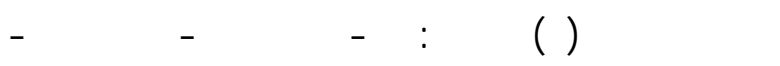

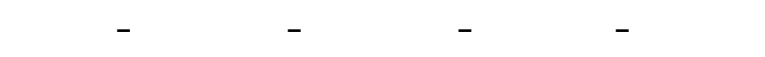

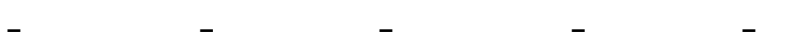

